\title{
Stage II Vulvar Cancer AJCC v6
}

National Cancer Institute

\section{Source}

National Cancer Institute. Stage I/ Vulvar Cancer A/CC v6. NCI Thesaurus. Code C9051.

Stage II includes: T2, N0, M0. T2: Tumor confined to the vulva or vulva and perineum, more than $2 \mathrm{~cm}$ in greatest dimension. N0: No regional lymph node metastasis. M0: No distant metastasis. (AJCC 6th ed.) - 2003 